Georgia State University

ScholarWorks @ Georgia State University

\title{
What Causes People to Change Their Opinion About Climate Change?
}

\author{
Risa Palm \\ Georgia State University, risapalm@gsu.edu \\ Gregory B. Lewis \\ Georgia State University, glewis@gsu.edu \\ Bo Feng \\ Georgia State University, bofeng1987@gmail.com
}

Follow this and additional works at: https://scholarworks.gsu.edu/geosciences_facpub

Part of the Geography Commons, and the Geology Commons

\section{Recommended Citation}

Palm, Risa; Lewis, Gregory B.; and Feng, Bo, "What Causes People to Change Their Opinion About Climate Change?" (2017). Geosciences Faculty Publications. 22.

https://scholarworks.gsu.edu/geosciences_facpub/22

This Article is brought to you for free and open access by the Department of Geosciences at ScholarWorks @ Georgia State University. It has been accepted for inclusion in Geosciences Faculty Publications by an authorized administrator of ScholarWorks @ Georgia State University. For more information, please contact scholarworks@gsu.edu. 
Abstract. After a decade of steady growth in the acceptance of the existence of climate change and its anthropogenic causes, opinions have polarized, with almost one-third of Americans, mostly Republicans, denying that the climate is changing or that human activity is responsible. What causes Americans to change their minds on this issue? Using a large panel data set, we examined the impacts of direct experience with weather anomalies, ideology, relative prioritization of environmental conservation in comparison to economic development, and motivated reasoning that adjusts individual opinion to align with others who share one's party identification. A generalized ordered logit model confirmed the importance of political ideology, party identification, and relative concern about environmental conservation and economic development on attitude change. The effect of party identification strengthened with attentiveness to news and public affairs, consistent with the logic of motivated reasoning. Recent experience with hot summers, warm winters, droughts, and natural disasters had only a minimal impact on attitude change.

Key Words: climate change, longitudinal survey, opinion change, motivated reasoning, political ideology 
The United States lags behind much of the world in support for action to mitigate climate change (Ipsos MORI, 2014). Almost one-third of Americans, primarily Republicans, believe either that climate change is not occurring or that it is not due to human activity (Riffkin, 2014; Leiserowitz et al, 2016; Mills et al, 2016). The Pew Research Center found that 79 percent of liberal Democrats, but only 15 percent of conservative Republicans believed that as a result of human activity, the earth is warming (Funk and Kennedy, 2016, 9).

Belief about the existence and causes of global climate change are also related to values concerning the relative importance of job growth as opposed to environmental conservation. As Heath and Gifford noted (2006, 65-66), “those who value the free market system over environmental quality tend to believe that global change is not occurring, that the causes of global climate change are more natural than human caused, and that its consequences will not be negative."

The process by which individuals develop and change their views about climate change is complex. In this paper, we demonstrate that a national sample of Americans changed their opinions between 2010 and 2014 primarily to align better with those who share their party identification and political ideology. This conforms with the theory of motivated reasoning: that evidence consistent with prior beliefs is viewed as strong, and that on politically salient issues, people strive to bring their opinions into conformance with those who share their political identity (Kahan et al., 2012).

Previous studies, aggregating cross-sectional surveys across time have identified trends and polarization in overall public opinion, but have not been able to track how individuals 
modify their attitudes over time. The contribution of this paper is its analysis of a nationally representative panel of 9500 respondents who were asked the same question about climate change in 2010 and 2014. These data provide the basis for the first large-sample empirical analysis of individual opinion change on global warming. Using these data, we identified people who maintained the same opinion as opposed to those who changed their opinions, becoming either more concerned or more skeptical about climate change. We then examined the relative importance of political ideology, party identification, relative concern about the environment in comparison with the economy, and recent experience with anomalous weather patterns on stability or shifts in opinion. The empirical analysis supports the theory of motivated reasoning: Americans tend to align their opinions on climate change to match those of others who share their political party or political ideology.

Findings About Beliefs in Climate Change from Cross-Sectional Studies Belief in the existence of climate change and its anthropogenic causes has not grown consistently in the United States. Based on a review of 240 articles published between 1980 and 2014, Capstick et al. (2015) showed that acceptance of the existence of climate change grew steadily from the 1980s through the early 1990s, but was more erratic in the next decade. More recently, skepticism has grown and opinions have polarized along political party lines. Studies from the Yale Project on Climate Change reported that although a slowly growing majority of Americans are worried about global warming, only a minority believe human action is causing it (Howe and Leiserowitz, 2013, Roser-Renouf et al., 2014). Furthermore, those who believe that the climate change is not changing have become more certain in their beliefs (Leiserowitz et al. 2015). 
A vast literature has examined trends in beliefs about the existence of and causes for climate change, and the correlates of these beliefs. The findings of this research form the basis of the hypotheses about the influence of four sets of variables on receptivity to messages about climate change: (1) opinion leaders or membership in a social network; (2) direct experience with weather events that could be linked to global climate change, (3) science education as well as general scientific literacy; and (4) demographic characteristics that pre-condition receptivity to messages about climate change.

\section{Influence of Opinion Leaders or Membership in a Social Network}

Early research suggested that a small number of "opinion leaders" shaped the influence of media on public opinion (Katz and Lazarsfeld, 1955; Lazarsfeld, Berelson, and Gaudet, 1968). Zaller (1992) added the modification that those who are either less attentive to or less aware of the messages being promulgated by the elite are less likely to accept them. Social networks and interactions can also influence the ways in which people form and change opinions (Watts and Dodds, 2007; Moussaid et al, 2013). People use several perspectives or "frames" to interpret information generally, especially information that has a highly political or emotional edge, and these frames matter more in opinion formation than the facts themselves (Chong and Druckman, 2007; Hoffman, 2015).

Both the framing of messages about climate change and the current association of the entire subject of climate change with political ideology have an overwhelming impact on acceptance of ideas about climate change (Bolsen, Druckman and Cook, 2014a, Brulle, Carmichael, and Jenkins, 2012, Druckman and Bolsen, 2011). Kahan (2015a, 12) found that simply providing more accurate scientific information to the general public does not change 
opinions, but instead reinforces prior views: "those whose cultural commitments predispose them to be concerned about climate change become even more so as their level of science comprehension increases." People selectively seek evidence that supports the position of the group with which they identify and dismiss evidence that contradicts it (van der Linden, 2015).

The phenomenon of seeking information that confirms prior beliefs is known as "motivated reasoning" or "confirmation bias" (Nickerson 1998; Kahan 2015b). One exhibits motivated reasoning when one "view[s] evidence consistent with prior opinions as stronger or more effective" (Druckman 2015, 60). When political party shapes motivated reasoning, this phenomenon is labelled "partisan motivated reasoning" (Bolsen et al., 2014, Bolsen et al., 2015) or "politically motivated reasoning" (Kahan, 2015). In this framing, individuals strive to shape their opinions on politically salient issues to conform with those of their party, reject information and ideas that conflict with party ideology, and become ever more convinced that their party's position is accurate (Kahan et al., 2012).

Political parties in the United States are sharply divided on climate change and its anthropogenic causes. While the Democratic party views climate change as an urgent problem, the Republican party tends to deny or downplay its significance. While the 2016 Democratic party platform characterizes climate change as "a real and urgent threat" and states that "Democrats share a deep commitment to tackling the climate challenge" (Democratic Party Platform Committee, 2016, 27), the Republican party platform notes that "climate change is far from this nation's most pressing national security issue" and opposes "any carbon tax" (Republican National Committee, 2016, 20). Further, many notable Republican leaders are not convinced that the planet is warming or that human activity is the primary driver of climate change (Gregoire, 2015; McCright, Dunlap and Xiao, 2014). This difference between 
conservative and liberal party positions seems to be unique to the United States (Båtstrand, 2015).

\section{Direct Experience with Environmental Hazards or Temperature Variability}

Some studies have found that personal experience with storms, floods, drought or temperature anomalies leads to greater acceptance of the existence of climate change. For example, respondents in the U.K. who had experienced flood damage expressed more concern about climate change (Spence et al., 2011). Similarly, Elrick-Barr et al (2015) studied two coastal communities in Australia that were equally vulnerable to climate hazards and found that it was not proximity to the coast, but instead prior experience with the hazard, that increased perceived risk. Brody et al (2008) also found only a weak relationship between proximity to flood-prone areas and risk perception, particularly in comparison with the impact of the personality variables they used as controls, including "perceived efficacy" and "new ecological values" (Brody et al, 2008, 88).

Several studies have focused on warmer summer or winter temperatures in affecting perceptions of climate change. Hamilton and Keim (2009) found that in U.S. regions accustomed to winter snow, relatively warm winters were associated with increased concern with climate change. Zaval et al. (2014) and Li, Johnson and Zaval (2011) found that respondents expressed greater concern about global warming on hot summer days, and speculated that people may substitute the current temperature for general trends when thinking about global warming. Similarly, Borick and Rabe $(2010,6)$ found that respondents identified "warmer temperatures in your area during recent years" as a major influence on their views that "the earth is getting warmer." In contrast, Egan and Mullin (2012) found that any effect of the daily temperature 
immediately before or at the time of the survey on opinion about global warming was likely to be temporary.

Three studies found that warmer-than-normal summers and winters had an effect, but only in combination with prior beliefs about climate (Howe and Leiserowitz, 2013, Hamilton and Stampone, 2013, Clayton et al., 2015). In contrast, Deryugina (2013) matched a sample of US adults from the Gallup Environmental Poll for 2003-2010 with local weather information, and found that short-run temperature fluctuations lasting between 1-14 days had no effect on beliefs about global warming. Even extreme events such as "Snowmaggedon" and Superstorm Sandy did not seem to alter climate change perception (Trenberth et al., 2015, Lehner and Stocker, 2015, Saad, 2015). In trying to account for this absence of effect, Mastandrea et al. (2006) hypothesized that Americans do not consider climate change to be as important and immediate as other environmental issues. Leiserowitz and $\operatorname{Broad}(2006,55)$ noted that the image that many Americans have of the impacts of global warming, such as melting polar icecaps, are distant from everyday experience: "most Americans lacked vivid, concrete, and personal-relevant affective images of climate change, which helps explain why climate change remains a relatively low priority national or environmental issue." In addition, many Americans believe that even if climate change does cause disruption, society will either adapt or find a technological solution.

Because of their mid-latitude location, Americans may also find it difficult to experience "climate change" directly, and for those who live in areas where summers and winters have sharply different temperature ranges, the experience of cold in the winter may erase the memory of the previous hot summer (Weber, 2010, Van Der Linden, 2014, Howe and Leiserowitz, 2013). Indeed, a recent survey found that some view climate change as a positive trend, particularly for 
those Americans who have experienced relatively mild winters between 1974 and 2013 (Egan and Mullin 2016).

Another issue that impedes a direct relationship between experienced weather and belief in climate change is the process that people must undertake to see the linkage. The probability that people connect weather patterns to global climate change is likely to be filtered by prior beliefs or ideology that affects the ways in which they process information. In addition, when people are exposed to weather anomalies but do not suffer serious consequences, they may become more confident that climate change is not occurring or that it is not serious (Saad, 2015, Brody et al., 2008)

Science education and scientific literacy

Some have hypothesized that directed science education about human-caused climate change can shift opinion overcoming ideological resistance. Guy et al. (2014) found such a pattern in Australia, and a 2008 survey in the United States (Borick and Rabe 2010) concluded that the 2007 report of the Intergovernmental Panel on Climate Change and Al Gore's documentary An Inconvenient Truth had a major impact on Americans' attitudes on global warming. Presumably in response to both sources of information, American respondents cited images of shrinking glaciers and polar ice as the most important issues affecting their belief in global warming. In contrast, however, the preponderance of survey research in the United States has shown that scientific articles or assessment reports do not move public opinion (Brulle et al., 2012, Hamilton, 2011, Hart and Nisbet, 2011, Zia and Todd, 2010). No matter how vivid the message or how strong the technical background of the audience, other factors are more important in shaping attitudes about climate change. 


\section{Demographic characteristics and receptivity to information about climate change}

Some research suggests that both gender and ethnicity may independently affect ideology or world-view, in turn shaping the receptivity to new information on climate change. Surveys have found that women are more concerned than men about climate change, perhaps due to differences in socialization and therefore the development of key values (McCright and Dunlap, 2011). White males tend to be relatively more hierarchical and individualistic, and, as a result, show greater skepticism about any kind of risk, including the deleterious effects of global climate change (Kahan et al., 2007, Finucane et al., 2000).

\section{Hypotheses}

In sum, cross-sectional surveys have provided overwhelming evidence that ideology, party identification, and attitudes about environmental conservation vs. economic development strongly influence beliefs about climate change in the U.S. Based on the theory of politically motivated reasoning, we hypothesized that people tend to shift their opinions over time to better match those of opinion leaders they respect, and that this effect is even stronger for those who pay more attention to messages from party elites. We also explored the effects of education levels and personal experience with hot summers, warm winters, droughts, and weather-related natural disasters on changing beliefs about climate change.

\section{Data and Methods}

The nine cross-sectional surveys that make up the Cooperative Congressional Election Study (CCES) have provided the basis for many scholarly studies. The CCES also includes a nationally representative $2010-14$ panel, which repeatedly asked 9500 respondents the same 
question about climate change. YouGov/Polimetrix administers the "opt-in" internet-based survey, that compensates respondents with rewards or points for every survey they complete (Ansolabehere and Schaffner, 2014). Schaffner and Ansolabehere (2015a; 2015b) described the detailed sampling strategy, sample matching algorithm, and theoretical background for the panel study. They noted that YouGov re-interviewed 83 percent of the 2010 panel sample in 2012 and 68 percent of the 2012 respondents in 2014. Although any attrition decreases the representativeness of panel surveys, the overall retention rate of 56 percent compares favorably to the 41 percent retention rates reported in the 2000-2004 American National Election Studies. Sample composition did not change markedly between 2010 and 2014; although attrition was somewhat higher for blacks and non-voters, attrition rates were generally similar among subgroups (Schaffner and Ansolabehere, 2015a; 2015b).

The dependent variable in this analysis was derived by comparing the 2010 and 2014 responses to the following question: "From what you know about global climate change or global warming, which one of the following statements comes closest to your opinion?

1. Global climate change has been established as a serious problem and immediate action is necessary,

2. There is enough evidence that climate change is taking place and some action should be taken,

3. We don't know enough about global climate change and more research is necessary before we take any actions,

4. Concern about global climate change is exaggerated and no action is necessary, or 5. Global climate change is not occurring and this is not a real issue." 
We coded the 65 percent who gave the same response in both years as 0 , the 17 percent who gave a lower-numbered answer in 2014 as -1, and the 18 percent who gave a higher-numbered answer in 2014 as +1 .

We measured all individual-level independent variables in 2010 and experiences with weather anomalies within the period between the two surveys. We used two dummy variables to distinguish Democrats and Republicans from independents, the reference group. To test whether partisan respondents sought partisan information, we tested the interaction between party identification and interest in public affairs as measured on a four-level scale, based on responses to the question: "Some people seem to follow what's going on in government and public affairs most of the time, whether there's an election going on or not. Others aren't that interested. Would you say you follow what's going on in government and public affairs most of the time, some of the time, only now and then, or hardly at all?"

We coded liberalism as a 5-point scale, ranging from 1 (very conservative) to 5 (very liberal). We measured attitudes about the relative importance of environmental conservation versus economic development based on 2010 responses to the question, "Some people think it is important to protect the environment even if it costs some jobs or otherwise reduces our standard of living. Other people think that protecting the environment is not as important as maintaining jobs and our standard of living. Which is closer to the way you feel, or haven't you thought much about this?" We coded this variable as 1 for those who said it was much more important to protect jobs and 5 for those who said it was much more important to protect the environment. To test the "white male" effect, we introduced nine dummy variables for white women, and black, Hispanic, Asian, and "other" men and women. 
Because the CCES identifies the respondent's county of residence, we were able to associate weather-related variables at the county level, using other data sets. To measure warm winters and hot summers, we used the mean January and July temperatures in the county from 2011 to 2014, minus the mean temperatures for the same month from 1950 to 2010 (Menne et al, 2010). Since most of the previous research has weather-related variables for much shorter periods ranging from that day's temperature (Egan and Mullin, 2012) to up to one year (Hamilton and Stampone, 2013), we also ran models using only data from the previous year. The effects were similar to those reported. The temperature data came from the Global Historical Climatology Network-Daily at National Oceanic and Atmospheric Administration. Across the entire sample, the average January temperature from 2011 through 2014 was slightly cooler $\left(0.1^{\circ} \mathrm{C}\right)$ than in $1950-2010$, but the average July temperature was $0.5^{\circ} \mathrm{C}$ higher than the baseline.

We measured experience with drought using the number of weeks between November 2010 and September 2014 that the county had moderate-to-extreme drought conditions (D1 to D4), using data from the United States Drought Monitor. Four measures of the severity of eight natural disasters in the county between November 2010 and September 2014 were analyzed: the natural logarithms of total fatalities, injuries, crop damage, and property damage due to coastal flooding, drought, flooding, heat, hurricane/tropical storm, severe storm/thunder storm, tornado, or winter weather (Hazards and Vulnerability Research Institute, 2014).

For the initial analysis, we compared the characteristics of people who did and did not change their opinions on climate change between 2010 and 2014. We tabulated the differences between changers and non-changers with respect to party identification, ideology, relative importance of environmental conservation, interest in public affairs, race/ethnicity, gender, age, 
and education. Given the overwhelming impact of political party identification on beliefs about climate change, we then focused on opinion change among respondents who identified with the same political party in 2010 and 2014.

We ran generalized ordered logit models to assess the impact of our independent variables on whether respondents became more skeptical, did not change, or became more concerned about climate change between 2010 and $2014 .{ }^{1}$ Because the weather-related variables are measured at the county level, we clustered the standard errors at the same level. ${ }^{2}$ We could not use simple ordered logit analysis because our model violated the proportionality of odds assumption. To ease interpretation, we did not report the coefficients from the Stata gologit2 command (Williams, 2005). Instead, we reported the marginal effects, also called the average partial effects or APE (Wooldridge, 2009).

\section{Opinion Change from 2010 to 2014}

Overall, the distribution of opinion on climate change was similar in 2010 and 2014. Changes tended to come at the two extreme ends of the spectrum: increases in those stating that climate change is not occurring or that climate change is a serious issue warranting action, balanced by small decreases in those stating that more research is needed (Table 1).

\footnotetext{
${ }^{1}$ Ordered logistic regression assumes that the independent variables have linear (constant) impacts on the natural logarithms of the odds, rather than on the probabilities, of each belief. Thus, the impact of each independent variable on the probabilities varies across individuals. The APE estimates the probability change for each individual in the data set, then calculates the mean of those changes.

${ }^{2}$ We also tested a multilevel mixed-effects ordered logistic regression using the Stata meologit command. The meologit command has a strength in recognizing that we are measuring the weather-related variables at the county level and the other variables at the individual level, but a weakness in not allowing us to relax the parallel odds assumption. Nonetheless, meologit did not meaningfully change the findings.
} 
Table 1 - Percentages Taking Each Position on Climate Change, 2010 and 2014

\begin{tabular}{lcc}
\hline & 2010 & 2014 \\
\hline Global climate change is not occurring & 6.2 & 7.6 \\
Concern is exaggerated; No action is needed & 19.5 & 19.5 \\
More research is needed & 20.0 & 18.4 \\
Enough evidence that climate change is taking place & 27.0 & 24.8 \\
Global climate change is a serious issue; Action need & 27.3 & 29.7 \\
Total & 100 & 100 \\
\hline \hline
\end{tabular}

Note: Sampling weight applied.

However, more than 35 percent of the respondents gave different responses in 2014 than they had in 2010. Although one would expect some level of variability in survey responses with a repeated survey over a four-year period of time, this volume of change exceeded the variability noted on other survey items such as opinions on the Affordability Care Act, granting legal status to immigrants or gun control (Schaffner and Ansolabehere, 2015a, 21).

The five responses were condensed into three categories (Table 2). The first category summarized those who are not concerned with global climate change: the combination of "Global climate change is not occurring and this is not a real issue" and "Concern about global climate change is exaggerated and no action is necessary." The second category "We don't know enough about global climate change and more research is necessary before we take any actions" remained the middle position. The third category was the combination of those concerned with global climate change: "Global climate change has been established as a serious problem and immediate action is necessary" and "There is enough evidence that climate change is taking place and some action should be taken." Cross-tabulations and chi squared tests compared the six groups off the diagonal to those in the same rows whose views remained the same between 2010 and 2014 (Table 3). 
Table 2 - Percentages Changing Opinions between 2010 and 2014

\begin{tabular}{lccc}
\hline \multicolumn{3}{c}{ Climate Change (2014) } \\
\hline $\begin{array}{l}\text { Climate Change (2010) } \\
\begin{array}{l}\text { Climate change is not } \\
\text { happening or is } \\
\text { exaggerated } \\
\text { happening or is } \\
\text { exaggerated }\end{array}\end{array}$ & $\begin{array}{c}\text { More } \\
\text { study is } \\
\text { needed }\end{array}$ & $\begin{array}{c}\text { Climate change is } \\
\text { occurring and demands } \\
\text { action }\end{array}$ \\
$\begin{array}{l}\text { More study is needed } \\
\begin{array}{l}\text { Climate change is } \\
\text { occurring and demands } \\
\text { action }\end{array}\end{array}$ & 25.2 & 19.1 & 3.5 \\
\hline \hline Note: Sampling weight applied. & 2.1 & 56.1 & 92.4 \\
\hline
\end{tabular}


Table 3 - Characteristics of Those Whose Opinions Changed

\begin{tabular}{|c|c|c|c|}
\hline & $\begin{array}{l}\text { 2014: climate change is } \mathrm{r} \\
\text { happening or is } \\
\text { exaggerated }\end{array}$ & $\begin{array}{l}\text { 2014: more study is } \\
\text { needed }\end{array}$ & $\begin{array}{l}\text { 2014: climate change is } \\
\text { occurring and demands } \\
\text { action }\end{array}$ \\
\hline $\begin{array}{l}\text { 2010: climate change } \\
\text { is not happening or } \\
\text { exaggerated }\end{array}$ & & $\begin{array}{l}\mathrm{N}=363 \\
\text { Moderate or liberal } \\
\text { ideology } \\
\text { Economy and } \\
\text { environment are of } \\
\text { equal importance } \\
\text { Moderate interest in } \\
\text { public affairs } \\
\text { Independent or } \\
\text { Democrat }\end{array}$ & $\begin{array}{l}\mathrm{N}=109 \\
\text { Below age } 50 \\
\text { Fewer post-graduate, mor } \\
\text { with "some college" } \\
\text { Female } \\
\text { Moderate, liberal ideolog. } \\
\text { Economy and environmer } \\
\text { are of equal importance } \\
\text { Democrat } \\
\text { NOT white male }\end{array}$ \\
\hline $\begin{array}{l}\text { 2010: more study is } \\
\text { needed }\end{array}$ & $\begin{array}{l}\mathrm{N}=532 \\
\text { Conservative to very } \\
\text { conservative } \\
\text { Economy is more } \\
\text { important than the } \\
\text { environment } \\
\text { Interested in public affain } \\
\text { most of the time } \\
\text { Republican }\end{array}$ & & $\begin{array}{l}=335 \\
\text { Below age } 65 \\
\text { Female } \\
\text { Moderate to liberal } \\
\text { Environment is somewhat } \\
\text { more important than the } \\
\text { economy } \\
\text { Some interest in public } \\
\text { affairs } \\
\text { Democrat } \\
\text { Nonwhite }\end{array}$ \\
\hline $\begin{array}{l}\text { 2010: climate chang } \\
\text { is occurring and } \\
\text { demands action }\end{array}$ & $\begin{array}{l}\mathrm{N}=101 \\
\text { More in age } 40-50 \text { group } \\
\text { fewer over } 50 \\
\text { Conservative to very } \\
\text { conservative } \\
\text { Less frequent for college } \\
\text { educated } \\
\text { Economy is more } \\
\text { important than } \\
\text { environment } \\
\text { Some interest in } \\
\text { public affairs } \\
\text { Republican }\end{array}$ & $\begin{array}{l}\mathrm{N}=281 \\
\text { NOT in California } \\
\text { Less well educated } \\
\text { Female } \\
\text { Conservative to very } \\
\text { conservative } \\
\text { Economic and } \\
\text { Environment are } \\
\text { equally important or } \\
\text { economy is more } \\
\text { important } \\
\text { Infrequent interest in } \\
\text { public affairs } \\
\text { Independent or } \\
\text { Republican } \\
\text { NOT white male }\end{array}$ & \\
\hline
\end{tabular}


Among those who said that climate change was not occurring in 2010, those who changed to saying that more research is needed in 2014 were more likely to be Democrats or independents, were moderate or liberal in ideology, placed equal importance on the economy and the environment, and showed moderate interest in public affairs. The very small percentage who shifted from a belief that climate change is not occurring to the belief that it is occurring were more likely to be female, Democrats, under age 50, moderate or liberal, not white males, had a moderate interest in public affairs, gave equal weight to the economy and environment, and had started but not completed college.

Among those who said that more study was needed in 2010, respondents who shifted to believing that climate change is not happening or is exaggerated were more likely to be conservative or very conservative, to value the economy and jobs over the environment, to be interested in public affairs most of the time, and to be Republican. Those whose opinions shifted in the opposite direction, stating in 2014 that climate change is occurring, were more likely to be under 65, female, nonwhite, moderate to liberal, Democrat, and to view the environment as somewhat more important than the economy.

Finally, respondents who said that climate change is occurring in 2010 but said that climate change is not happening or is exaggerated in 2014 were more likely to be age 40-to-50, conservative to very conservative, Republican, to believe the economy is more important than the environment, and to have some interest in public affairs. The respondents who shifted to calling for more research on whether climate change is occurring by 2014 were less well educated, female, Republican, conservative to very conservative, felt the economy is equally or slightly more important than the environment, and were infrequently interested in public affairs. 
Opinion Change Among Republicans, Democrats and Independents

To test the theory of motivated reasoning, we next focused on how political party affiliation affected the strength and direction of such change. For this analysis, we restricted the sample to the 85 percent $(8,113$ respondents) who had not changed their political party affiliation between 2010 and 2014.

Overall, a much small proportion of these respondents, 18 percent compared to the 35 percent noted for the full sample, had changed their opinion over the 2010-2014 time period. We found the impact of political party on the direction of change overwhelming (Table 4).

Democrats were even more likely to attest that climate change is occurring and that this change demands action: the largest percentage of opinion changers were in the category of those who had formerly said more research was needed, and now were convinced that climate change was occurring. On the other hand, Republicans were more likely to become more skeptical about climate change: 48.2 percent remained skeptical about climate change throughout the study period, and an additional 11.1 percent who had previously stated that more research was needed, reported by 2014 that climate change is not occurring or is exaggerated. 


\section{Table 4. Attitude Change by Party Identification}

Climate Change not occurring 2010

Climate Change not occurring 2014

More research in 2014

Climate change occurring in 2014

$$
\text { Sample size }
$$

More research needed in 2010

Climate Change not occurring 2014

More research in 2014

Climate change occurring in 2014

$$
\text { Sample size }
$$

Climate Change occurring 2010

Climate Change not occurring 2014

More research in 2014

Climate change occurring in 2014

$$
\text { Sample size }
$$

\section{Republican Independent Democrat}

$\begin{array}{rrr}84.7 & 73.4 & 48.5 \\ 12.8 & 17.1 & 28.2 \\ 2.5 & 9.5 & 23.3 \\ & & \\ 017 & 158 & 103\end{array}$

38.2

20.0

12.4

50.8

51.0

10.9

29.0

48.8

1025

145

242

$\begin{array}{rrr}9.5 & 2.8 & 0.6 \\ 22.8 & 10.4 & 2.4 \\ 67.7 & 86.7 & 96.9 \\ & & \\ 504 & 316 & 3403\end{array}$

The geographic pattern of opinion change when stratified by political party is complex

(Figure 1). Republicans who shifted from asking for more research in 2010 to being convinced that climate change is not occurring tended to be more concentrated in the southeastern part of the United States and in relatively more rural or suburban counties where they are likely to hold local majorities.

A generalized ordered logit analysis permits the identification of the relative importance of the independent variables (Table 5). Each row shows how a one-unit increase in the independent variable changes the average probability of becoming more skeptical about, keeping the same opinion on, or becoming more convinced of global climate change. Within each row, the probability changes sum to zero. Thus, for example, a one-point rise in the relative 
importance one placed on the environment relative to jobs in 2010 led to a 4.5 percent drop in one's probability of becoming more skeptical about climate change by 2014 . This is offset by a 4.3 percent increase in one's probability of becoming more concerned, and a 0.3 percent increase in one's probability of not changing one's position. Similarly, respondents who were one level more liberal in 2010 were 4.8 percent more likely to increase their concern about climate change and 5.1 percent less likely to become more skeptical.

Republicans who almost never followed the news about public affairs were 9.5 percent more likely than comparable independents to become more concerned about climate change and 10.7 percent less likely to become more skeptical. Democrats who almost never followed the news were 11.3 percent more likely than comparable independents to increase their concern and insignificantly less likely to increase their skepticism. In other words, low-information Democrats were only 1.8 percent more likely than low-information Republicans to increase their concern and 8.4 percent less likely to become more skeptical.

For those interested in news and public affairs, however, the partisan effects were clear. Following the news did not change the opinion of independents much, but each one-point rise on the four-point news interest scale increased Republicans' probability of becoming more skeptical about climate change by 5.7 percent and decreased their probability of becoming more concerned by 3.2 percent. In contrast, following the news reduced Democrats' chances of becoming more skeptical; each one-point rise on the four-point news interest scale reduced their probability of greater skepticism by 3.3 percent. Thus, each one-point rise in news interest widened the gap between Republicans and Democrats by 9 percent. This is strong evidence for the motivated reasoning hypothesis: individuals find information to confirm the general ideology of the group to which they belong, and shift their beliefs towards the modal belief of their reference group. 
We found little evidence that direct experience with warmer weather, droughts, and weather-related natural disasters affected opinions about climate change. Of the weather-related independent variables, only warm winters had a statistically significant impact: a one-degree increase in average January temperatures relative to the baseline is associated with a 0.8 percent increase in the probability of rising concern and a 0.9 percent decrease in the probability of greater skepticism (Table 5). The impacts of hot summers, droughts, and natural disasters on change in opinion were not statistically distinguishable from zero.

The impacts of other variables on opinion change were weaker and less consistent. Moreeducated and older respondents were less likely to become more skeptical about climate change. We found little evidence for the white male effect. Only "other" females were more likely than comparable white men to increase their concern about climate change between 2010 and 2014. Black women and black, Hispanic, and "other" men were all about 5 percent more likely than comparable white men to increase their skepticism. 
Table 5. Changes in Opinions, 2010-2014

Average Partial Effects from Generalized Ordered Logit Model

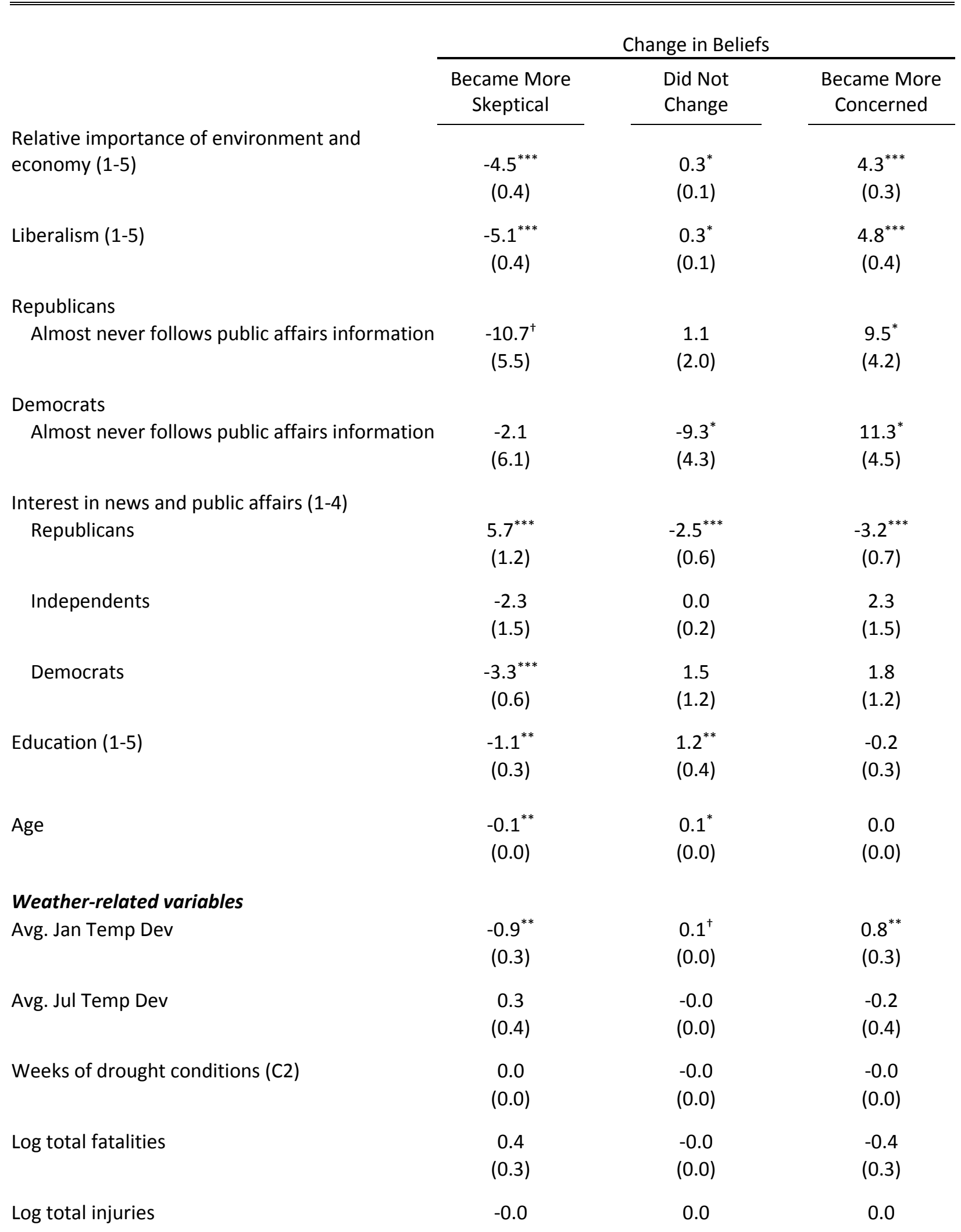




\begin{tabular}{lccc} 
& $(0.2)$ & $(0.0)$ & $(0.2)$ \\
Log total crop damages & 0.0 & -0.0 & -0.0 \\
& $(0.1)$ & $(0.0)$ & $(0.0)$ \\
Log total property damages & -0.1 & 0.0 & 0.1 \\
& $(0.1)$ & $(0.0)$ & $(0.1)$ \\
White male effect? & & & 0.7 \\
White female & -0.8 & 0.0 & $(0.6)$ \\
& $(0.7)$ & $(0.0)$ & $-4.8^{* *}$ \\
Black female & $5.1^{* *}$ & $-0.3^{+}$ & $(1.6)$ \\
& $(1.7)$ & $(0.2)$ & -2.2 \\
Hispanic female & 2.3 & -0.1 & $(2.1)$ \\
& $(2.2)$ & $(0.1)$ & $7.5^{*}$ \\
Other female & 3.8 & $-11.3^{* *}$ & $(3.1)$ \\
& $(3.6)$ & $(3.8)$ & 0.6 \\
Black male & $6.4^{*}$ & $-7.0^{*}$ & $(2.4)$ \\
Hispanic male & $(2.6)$ & $(3.0)$ & 3.3 \\
Other male & $5.0^{*}$ & $-8.3^{* *}$ & $(2.3)$ \\
Observations & $(2.0)$ & $(2.6)$ & $-4.6^{*}$ \\
\hline \hline
\end{tabular}

Standard errors, clustering at the county level, are in parentheses

${ }^{+} p<0.10,{ }^{*} p<0.05,{ }^{* *} p<0.01,{ }^{* * *} p<0.001$

Respondent's belief of climate change in 2010 is included in the model

\section{Conclusions}

Americans are becoming more polarized along partisan lines, and that change tends to bring the individual in line with the modal view of the political or ideological group with which the person identifies. An overwhelming number of Democrats strongly believe that climate change is occurring and that immediate action is required. Independents are also somewhat moving towards this point of view, although in smaller percentages. Republicans, on the other 
hand, generally remained convinced that climate change is not occurring or that its seriousness is exaggerated, and even those who sought more research on the topic in 2010 tended to become more skeptical of the existence of climate change by 2014. This vast difference in perspective is also reflected in the 2016 political party platforms on climate change. Democrats view climate change as "an urgent threat" and a "defining challenge," while the Republican platform pledges to defeat the Clean Power Plan to cut energy sector greenhouse emissions and rejects the 2015 Paris UN agreement on climate change.

Using repeated surveys on the same individuals over a four-year period, this analysis suggests that the direction of change in opinion is clearly related to respondents' political and environmental ideology, particularly when they pay more attention to public affairs: those most engaged and interested in public affairs seem to be seeking information that confirms the positions that their political ideology would suggest, resulting in confirmation and strengthening of their opinions over time. This is strong evidence for the theory of motivated reasoning in accounting for the changing opinion of Americans with respect to climate change.

In contrast, direct experience with indicators of climate change had little impact on changes in beliefs and attitudes. Experience with hotter summers, drought, and natural disasters did not have clear impacts on attitude change.

The absence of growth in acceptance of climate change since 1990, the increase in partisan polarization of opinion, and the finding that direct experience with drought or warmer summer temperatures has had little or no impact on belief in the existence of climate change suggest that the attitudes of Americans are not very susceptible to influences outside of political and economic ideology. Our findings portend that even with news of more summer heat, massive 
fires, drought and record-breaking storms, an important portion of the population will not accept evidence of global climate change. 


\section{References}

Ansolabehere, Stephen and Brian Schaffner. Cooperative Congressional Election Study: 2010-2014

Panel Study [Computer File] Release 1: June 10, 2015. Amherst, MA: University of

Massachusetts, Amherst [producer]. Available from http://dx.doi.org/10.7910/DVN/XFXJVY.

_ 2014. Does survey mode still matter? Findings from a 2010 multi-mode comparison.

Political Analysis 22: 285-303 doi: 10.1093/pan/mpt025. (last accessed 27 April, 2016).

Båtstrand, Sondre. 2015. More than markets: a comparative study of nine conservative parties on climate change. Politics and Policy 43(4): 538-561.

Bolsen, Toby, James N. Druckman, and Fay Lomax Cook. 2014a. How frames can undermind support for scientific adaptations: politicization and the status-quo bias. Public Opinion Quarterly 78:1-26.

. 2014b. The influence of partisan motivated reasoning on public opinion. Political Behavior

36: $235-262$.

- 2015. Citizens', scientists', and policy advisors' beliefs about global warming. The ANNALS of the American Academy of Political and Social Science 658: 271-295.

Borick, Christopher P. and Barry G. Rabe. 2010. A reason to believe: examining the factors that determine individual views on global warming. Social Science Quarterly: 91: 777-800.

Braman, Donald, Dan M. Kahan, Ellen Peters, Maggie Wittlin, Paul Slovic, Lisa Larrimore Ouellette, and Gregory N. Mandel. 2012. The polarizing impact of science literacy and numeracy on perceived climate change risks. Nature Climate Change 2: 732-735. 
Brody, Samuel D., Sammy Zahran, Arnold Vedlitz, and Himanshu Grover. 2008. Examining the relationship between physical vulnerability and public perceptions of global climate change in the United States. Environment and Behavior 40 (1): 72-95.

Brulle, Robert J., Jason Carmichael, and J. Craig Jenkins. 2012. Shifting public opinion on climate change: An empirical assessment of factors influencing concern over climate change in the US, 2002-2010. Climatic Change 114: 169-188

Capstick, Stuart, Lorraine Whitmarsh, Wouter Poortinga, Nick Pidgeon, and Paul Upham. 2015. International trends in public perceptions of climate change over the past quarter century. WIREs Climate Change 6: 35-61.

Chong, Dennis and James N. Druckman, 2007/ A theory of framing and opinion formation in competitive elite environments. Journal of Communication 57 (1): 99-118.

Clayton, Susan, Patrick Devine-Wright, Paul C. Stern, Lorraine Whitmarsh, Amanda Carrico, Linda Step, Janet Swim and Mirilia Bonnes. 2015. Psychological research and global climate change. Nature Climate Change 5 (7): 640-646.

Democratic Party Platform Committee, 2016. https://www.demconvention.com/wpcontent/uploads/2016/07/Democratic-Party-Platform-7.21.16-no-lines.pdf Last accessed 26 August 2016.

Deryugina, Tatyana. 2013. How do people update? The effects of local weather fluctuations on beliefs about global warming. Climatic Change 118: 397-416.

Druckman, James N. 2015. Communicating policy-relevant science. PS: Political Science \& Politics 48: 58-69.

Druckman, James N. and Toby Bolsen. 2015. Framing, motivated reasoning, and opinions about emergent technologies. Journal of Communication 61: 659-688. 
Dunlap, Riley E., and Aaron M. McCright. 2008. A widening gap: Republican and Democratic views on climate change. Environment: Science and Policy for Sustainable Development 50 (5): 26-35. Egan, Patrick J. and Megan Mullin. 2012. Turning personal experience into political attitudes: The effect of local weather on Americans' perceptions about global warming. Journal of Politics 74 (3): 796-809.

- 2016. Recent improvement and projected worsening of weather in the United States. Nature 532: $357-360$.

Elrick-Barr, Carmen E., Timothy F. Smith, Dana C. Thomsen and Benjamin L. Preston. Perceptions of risk among households in two Australian coastal communities. Geographical Research 53 (2): $145-159$.

Finucane, Melissa L., Paul Slovic, C. K. Mertz, and Stephen M. Johnson. 2000. Gender, race, and perceived risk: The “white male' effect. Health, Risk \& Society 2 (2): 159-172.

Funk, Cary, and Brian Kennedy. 2016. The Politics of Climate. Pew Research Center. file:///C:/Users/glewis/Downloads/PS_2016.10.04_Politics-ofClimate_FINAL\%20(1).pdf (last accessed 20 October, 2015)

Gregoire, Caroline, 2015. "Why some conservatives can't accept that climate change is real." The Huffington Post, December 4, 2015. http://www.huffingtonpost.com/entry/climate-changedenial-psychology_us_56438664e4b045bf3ded5ca5 (last accessed 26 August, 2016).

Guy, Sophie, Hoshihisa Kashima, Iain Walker and Saffron O'Neill. 2014. Investigating the effects of knowledge and ideology on climate change beliefs. European Journal of Social Psychology 44 (5): 421-429. 
Hazards and Vulnerability Research Institute. 2014. The Spatial Hazard Events and Losses Database for the United States, Version 12.0 [Online Database]. University of South Carolina, Columbia, SC. http://hvri.geog.sc.edu/SHELDUS/. (last accessed 27 April, 2016).

Hamilton, Lawrence C. and Barry D. Keim. 2009. Regional variation in perceptions about climate change. International Journal of Climatology 29: 2346-2352.

- 2011. Education, politics and opinions about climate change: Evidence for interaction effects. Climatic Change 104 (2): 231-242.

Hamilton, Lawrence C., and Mary D. Stampone. 2013. Blowin' in the wind: Short-term weather and belief in anthropogenic climate change. Weather, Climate and Society 5: 112-119.

Hart, P. Sol and Erik C. Nisbet. 2011. Boomerang effects in science communication: how motivated reasoning and identity cues amplify opinion polarization about climate mitigation policies. Communication Research 30 (1): 48-71.

Heath, Yuko and Robert Gifford. 2006. Free-market ideology and environmental degradation: The case of belief in global climate change. Environment and Behavior 38 (1): 48-71.

Hoffman, Andrew J. 2015. How Culture Shapes the Climate Change Debate. California: Stanford University Press.

Howe, Peter D., and Anthony Leiserowitz. 2013. Who remembers a hot summer or a cold winter? The asymmetric effect of beliefs about global warming on perceptions of local climate conditions in the U.S. Global Environmental Change 23 (6): 1488-1500.

IPSOS MORI, 2014. Global Trends: 2014. Environment. http://www.ipsosglobaltrends.com/environment.html (last accessed 27 April 2015).

Kahan, Dan M.. 2015a. Climate-science communication and the measurement problem. Advances in Political Psychology 36 (S1): 1-43. 
. 2015b. The politically motivated reasoning paradigm. Emerging Trends in Social \& Behavioral Sciences. http://ssrn.com/abstract=2703011 (last accessed 27 April, 2016). Kahan, Dan M., Donald Braman, John Gastil, Paul Slovic, and C. K. Mertz. 2007. Culture and identity-protective cognition: Explaining the white male effect in risk perception. Journal of Empirical Legal Studies 4 (3): 465-505.

Kahan, Dan M., Ellen Peters, Maggie Wittlin, Paul Slovic, Lisa Larrimore Ouellette, Donald Braman, and Gregory N. Mandel. 2012. The polarizing impact of science literacy and numeracy on perceived climate change risks. Nature Climate Change, 2: 732-35.

Kahan, Dan M., Ellen Peters, Donald Braman, Paul Slovic, Maggie Wittlin, Lisa Larrimore Ouelette, and Gregory Mandel. 2011. "The tragedy of the risk-perception commons: Culture conflict, rationality conflict, and climate change." Working Paper 89, Yale Law School, Cultural Cognition Project, Yale University, New Haven, CT. https://www.law.upenn.edu/live /files/296-kahan-tragedy-of-the-riskperception1pdf (last accessed 27 April, 2016).

Katz, Elihu and Paul Felix Lazarsfeld, 1955. Personal Influence: the part played by people in the flow of mass communications. Glencoe, Il: Free Press.

Lazarsfeld, Paul, Bernard Berelson, and Hazel Gaudet, 1968. The People's Choice: how the voter makes up his mind in a presidential campaign. New York: Columbia University Press.

Lehner, Flavio, and Thomas F. Stoker. 2015. From local perception to global perspective. Nature Climate Change 5: 731-35.

Leiserowitz, Anthony A. and Kenneth Broad. 2006. Climate change risk perception and policy preferences: The role of affect, imagery and values. Climate Change 77: 45-72. 
Leiserowitz, Anthony, A., Edward Maibach, Connie Roser-Renoug, Geoff Feinberg, and Seth

Rosenthal. 2015. Climate change in the American mind: October, 2015. Yale Project on

Climate Change Communication, Yale University and George Mason University, New Haven,

CT, 2015. http://environment.yale.edu/climate-communication-OFF/files/Climate-Change-

American-Mind-October-2015.pdf (last accessed 27 April, 2016).

2016. Climate change in the American mind: Spring 2016. Yale Project on Climate

Change Communication, Yale University and George Mason University, New Haven, CT,

Yale Program on Climate Change Communication.

Li, Ye, Eric J. Johnson and Lisa Zaval. 2011. Local warming: Daily temperature deviation affects beliefs and concern about climate change. Psychological Science 22: 454-459.

Mastrandrea, Michael D., Amy L. Luers, and Stephen H. Schneider. 2006. Changing perceptions of changing risks: Climate change and the California public. Climate Change Project Policy Brief, Woods Institute for the Environment, Stanford University, Stanford, CA.

McCright, Aaron M., and Riley E. Dunlap. 2011. The politicization of climate change and polarization in the American public's views of global warming, 2001-2010. The Sociological Quarterly 52 (2): 155-194.

McCright, Aaron M., Raley E. Dunlap and Chenyang Xiao, 2014. Increasing influence of party identification on perceived scientific agreement and support for government action on climate change in the United States, 2006-2012. AMS Journals online, DOI: http://dx.doi.org/10.1175/WCAS-D-13-00058.1 (last accessed 26 August, 2016).

Menne, Matthew J., Imke Durre, Russell S. Vose, Byron E. Gleason and Tamara G. Houston. 2012. An overview of the Global Historical Climatology Network-Daily Database. Journal of Atmospheric and Oceanic Technology 29: 897-910. 
Mills, Sarah B., Christopher Borick, and Barry G. Rabe. 2016. Fewer Americans Doubt Global Warming is Occurring: a report from the National Surveys on Energy and Environment. Issues in Energy and Environmental Policy (29, July 2016).

Moussaîd, Mehdi, Juliane E. Kåmmer, Pantelis P. Analytis, and Hansjørg Neth. 2013. Social influence and the collective dynamics of opinion formation.

http://dx.doi.org/10.1371/journal.pone.0078433 (last accessed 10 August 2016).

Nickerson, Raymond S. 1998. Confirmation bias: A ubiquitous phenomenon in many guises. Review of General Psychology 2 (2): 175-220. doi:10.1037/1089-2680.2.2.175

Republican National Committee, 2016. https://prod-static-ngoppbl.s3.amazonaws.com/media/documents/DRAFT_12_FINAL[1]-ben_1468872234.pdf (Last accessed 26 August, 2016).

Riffkin, R., 2014. Climate change not a top worry in US. Politics, March 12, 2014. http://www.gallup.com/poll/167843/climate-change-not-top-worry.aspx. (last accessed 27 April, 2016).

Roser-Renouf, Connie, Edward Maibach, Anthony Leiserowitz, Geoff Feinberg, Seth Rosenthal, and Jennifer Kreslake. 2014. Global warming's six Americas, October, 2014: Perception of the health consequences of global warming and update on key beliefs. Yale University and George Mason University. New Haven, CT: Yale Project on Climate Change Communication.

Saad, Lydia. "A steady 57\% in U.S. blame humans for global warming," Gallup. Last modified March 18, 2014. http://www.gallup.com/poll/167972/steady-blame-humans-globalwarming.aspx . "U.S. views on climate change stable after extreme winter," Gallup. Last modified March 25, 2015. http://www.gallup.com/poll/182150/views-climate-change-stable-extreme-winter.aspx 
Schaffner, Brian F., and Stephen Ansolabehere. 2015a . CCES Panel 2010-2014.

https://ccesconference.byu.edu/Documents/schaffner_presentation_sundance.pdf (last accessed 27 April, 2016).

. Guide to the 2010-2014 CCES Panel Study. Data Release: No. 1, June 10, 2015 b.

http://projects.iq.harvard.edu/cces/book/study-design (last accessed 23 August, 2016).

Spence, Alexa, Wouter Poortinga, Catherine Butler, and Nick F. Pidgeon. 2011. Perceptions of climate change and willingness to save energy related to flood experience. Nature Climate Change 1: 46-49.

Stata, Version 14. StataCorp LP, College Station Texas, USA

Trenberth, Kevin E., John T. Fasullo, and Theodore G. Sheperd. 2015. Attribution of climate extreme events. Nature Climate Change 5: 725-730.

van der Linden, Sander. 2014. On the relationship between personal experience, affect and risk perception: The case of climate change. European Journal of Social Psychology 44 (5): 430440.

- 2015. The social-psychological determinants of climate change risk perceptions: Towards a comprehensive model. Journal of Environmental Psychology 41: 112-124.

Watts, Duncan J. and Peter Sheridan Dodds. Influentials, Networks, and Public Opinion Formation. Journal of Consumer Research 34 (4):441-458.

Weber, Elke U. 2010. What shapes perceptions of climate change? WIRES Climate Change 1: 332342.

Williams, Richard A. 2005. Gologit2: A program for generalized logistic regression/partial proportional odds models for ordinal dependent variables. http://www.stata.com/meeting/4nasug/gologit2.pdf. (last accessed 27 April, 2016). 
Wooldridge, Jeffrey M, 2010. Econometric Analysis of Cross Section and Panel Data, Second Edition. Cambridge, MA: MIT Press.

Zaller, John R. 1992. The Nature and Origins of Mass Opinion. Cambridge: Cambridge University Press.

Zavel, Lisa, Elizabeth A. Keenan, Eric J. Johnson, and Elke U. Weber. 2014. How warm days increase belief in global warming. Nature Climate Change 4: 143-47.

Zia, Asim, and Anne Marie Todd. 2010. Evaluating the effects of ideology on public understanding of climate change science: How to improve communication across ideological divides?" Public Understanding of Science 19 (6): 743-761.

RISA PALM is Professor in the Department of Geosciences and Provost at Georgia State University, Atlanta, GA 30302. Email: risapalm@gsu.edu. Her research interests include natural hazards and climate change response and urban geography.

GREGORY B. LEWIS is Professor and Chair of the Department of Public Management and Policy in the Andrew Young School of Policy Studies at Georgia State University. Email:

glewis@gsu.edu. His research focuses on public opinion on LGBT rights and on diversity issues in public employment.

BO FENG is Ph.D. candidate in the Department of Public Management and Policy in the Andrew Young School of Policy Studies at Georgia State University. Email: bfeng1@gsu.edu. His research interests lie broadly within public policy, with specific interest within the field of health economics. 
